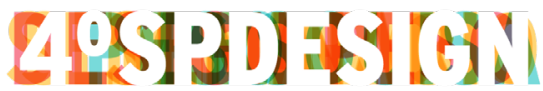 \\ Seminário de Pesquisa \\ Programa de Pós-Graduação \\ Design FAU USP
}

\section{Ajuste de imagens fotográficas para análise de letreiros presentes na paisagem urbana paulistana do início do século XX}

\author{
Fabio Mariano Cruz Pereira, Priscila Lena Farias
}

\section{Ajuste de perspectiva; fotografia; letreiro; oficinas tipográficas}

Este estudo apresenta um procedimento para ajuste de imagens fotográficas selecionadas como parte do corpus da pesquisa 'A Identificação Gráfica das Oficinas Tipográficas Paulistanas: 19001930'. Esta pesquisa tem por objetivo verificar a existência de recorrências no uso de elementos de linguagem gráfica para a identificação de oficinas tipográficas do início do século XX que evidenciem estratégias de comunicação visual semelhantes ao que hoje é reconhecido pelo campo do design como logotipo, marca gráfica e identidade visual. Para isso, fotografias e artefatos impressos estão sendo consultados, registrados, catalogados e analisados. Durante os procedimentos de organização e tratamento de dados, fotografias realizadas em São Paulo durante o início

Curso

Doutorado

\section{Linha de Pesquisa}

Teoria e História do Design

\section{Fabio Mariano Cruz Pereira}

Designer gráfico e doutorando em

Design pela Universidade de São

Paulo (USP, Brasil) e Università

IUAV di Venezia (IUAV, Itália).

Bolsista FAPESP 2018/03383-1.

e-mail: fabiomariano@usp.br

Lattes: http://lattes.cnpq.

br/6379117193624957

Orcid: https://orcid.org/0000-

0003-0757-072X

\section{Priscila Lena Farias}

Professora Associada e coordenadora do LabVisual Laboratório de Pesquisa em Design Visual na FAU USP. Autora de diversos artigos e livros sobre tipografia, semiótica e design.

Seus interesses atuais de pesquisa são história da tipografia e letreiramento no espaço público.

e-mail: prifarias@usp.br

Lattes: http://lattes.cnpq. $\mathrm{br} / 7204930940034076$

Orcid: http://orcid.org/00000002-2540-770X do século $X X$, retratando inscrições contendo nomes de oficinas tipográficas, foram catalogadas e descritas. Parte dos letreiros registrados nessas fotografias foram distorcidos pela perspectiva, o que dificulta a análise das letras presentes neles. Observou-se então a necessidade de adotar ferramentas de edição de imagem que permitissem ajustar os letreiros. Procedimentos similares foram adotados em outras pesquisas (Gouveia, Farias \& Gatto 2010; Farias, Aragão, Cunha Lima 2012). As ferramentas 'Distorção de perspectiva' e 'Transformação livre' do software Adobe Photoshop foram utilizadas para obter versões planificadas dos letreiros. A próxima etapa da pesquisa envolve comparar as composições contendo os nomes de empresas obtidas por este processo com aquelas presentes em artefatos impressos. 


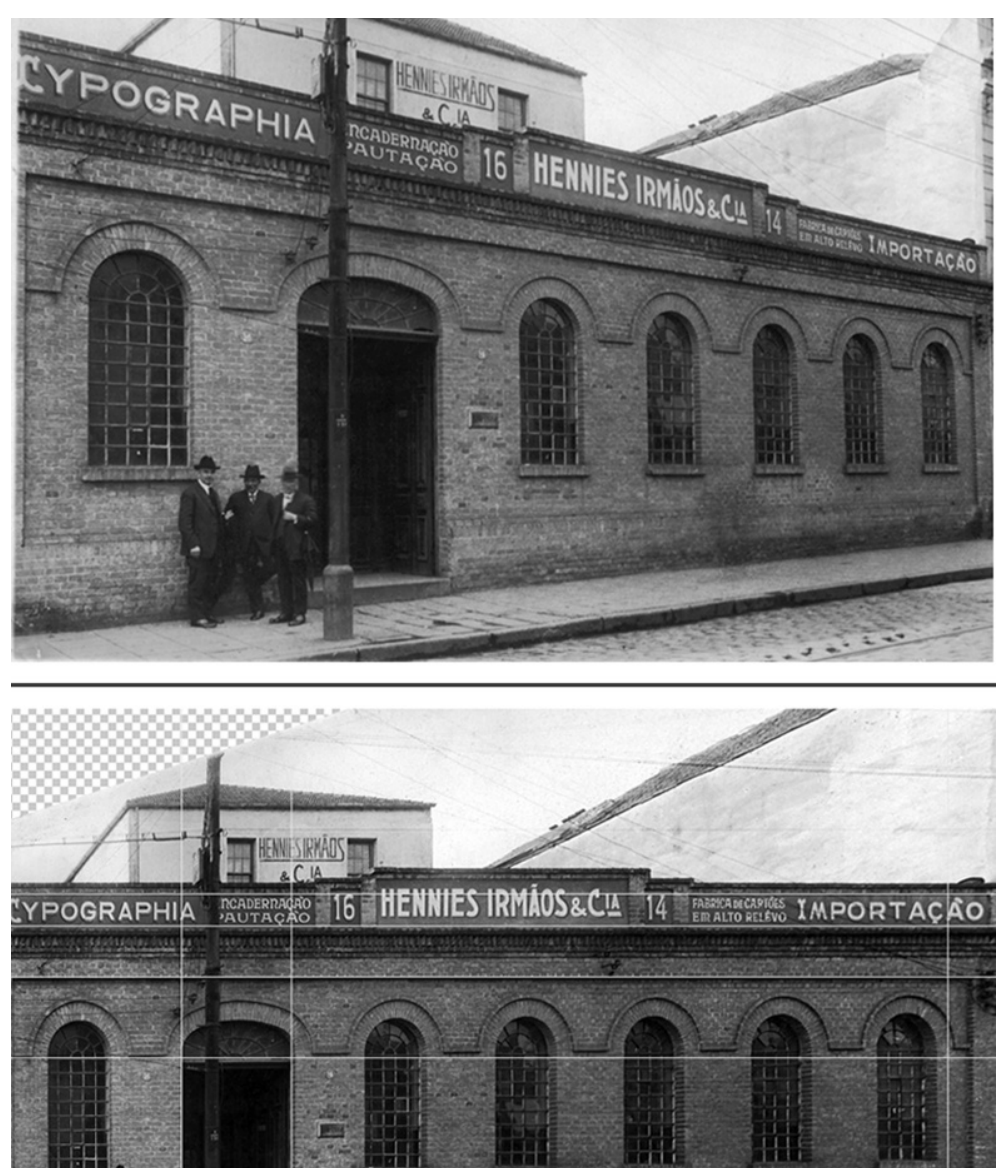

Fig. 1 Acima: fachada de Hennies Irmãos, c. 1905, família Hennies. Abaixo: ajuste de Jade Piaia, 2020. | Above: façade of Hennies Irmãos, c. 1905, Hennies family. Below: image adjusted by Jade Piaia, 2020.

Doctoral

\section{Line of Research}

Design Theory and History

\section{Fabio Mariano Cruz Pereira}

Graphic designer and a PhD candidate at the University of São Paulo (USP, Brazil) and IUAV University of Venice (IUAV, Italy). FAPESP grant \#2018/03383-1.

e-mail: fabiomariano@usp.br

Lattes: http://lattes.cnpq.

br/6379117193624957

Orcid: https://orcid.org/00000003-0757-072X

\section{Priscila Lena Farias}

Associate Professor and coordinator of LabVisual - Visual Design Research Lab at FAU USP. Author of several articles and books on typography, semiotics and design. Her current research interests are the history of typography, and lettering in the public space.

e-mail: prifarias@usp.br

Lattes: http://lattes.cnpq. br/7204930940034076 Orcid: http://orcid.org/00000002-2540-770X

\section{Photographic images adjustments for the analysis of signboards in São Paulo early 20th century urban landscape}

Fabio Mariano Cruz Pereira, Priscila Lena Farias

\section{adjustment of perspective; photography; signboards; letterpress printing shops}

This study presents a procedure for the adjustment of photographic images selected as part of the research corpus of the ongoing investigation 'The Graphic Identification of the Letterpress Printing Shops in São Paulo, 1900-1930' . This investigation aims to verify the existence of recurrences in the use of graphic language elements for the identification of letterpress print shops evidencing strategies similar to what is nowadays recognized in the design field as logotypes, graphic marks and visual identities. For this, photographs and printed artifacts are being consulted, registered, cataloged, and analyzed. During the procedures for organizing and processing data, photographs taken in São Paulo during the early 20th century, featuring signs containing the names of letterpress printing shops were cataloged and described. Part of the signboards registered in 
these photographs were distorted by perspective, making it difficult to analyze the letters they contain. The need for adopting image editing tools that would allow for the adjustment of the signs was thus observed. Similar procedures were adopted in other studies (Gouveia, Farias \& Gatto 2010; Farias, Aragão \& Cunha Lima 2012). The Adobe Photoshop tools 'Perspective Warp' and 'Free transform' were used in order to obtain flat versions of the signs. The next step of the research involves comparing the compositions containing the names of the companies obtained through this process with those present in printed artifacts.

\section{Referências | References}

FARIAS, P.; ARAGÃO, I. \& CUNHA LIMA, E. 2012. Unraveling aspects of Brazilian design history through the study of 19th century almanacs and type specimens. In: DRS 2012 Bangkok, v. 2: 498-511. Bangkok: Chulalongkorn University.

GOUVEIA, A.; FARIAS, P. \& GATTO, P. 2010. Acervo epigráfico paulistano: etapas e procedimentos de construção. In: Anais do $9^{\circ}$ Congresso Brasileiro de Pesquisa e Desenvolvimento em Design: 1095-1114. São Paulo: Universidade Anhembi Morumbi. 